\title{
IEМАГОГUKA
}

\author{
УДК 378.091.12-054.164:81'221.24'25|:005.336.2 \\ DOI https://doi.org/10.24919/2308-4863.1/27.203375
}

\author{
Наталія АДАМЮК, \\ orcid.org/0000-0002-4927-6257 \\ кандидат педагогічних наук, \\ старший науковий співробітник відділу навчання жестової мови \\ Інституту спеціальної педагогіки і психологї імені Миколи Ярмаченка \\ Начіональної академії педагогічних наук Украӥни \\ (Київ, Україна) natbor07@gmail.com
}

\section{ФАХОВА КОМПЕТЕНТНІСТЬ ОСВІТНІХ ПЕРЕКЛАДАЧІВ ЖЕСТОВОЇ МОВИ}

У статті перераховано низку міжнародних і національних документів, після яких розпочалася докорінна зміна освітньої політики щзодо сочіального захисту та мовних прав Глухих. Зазначено, щзо до останніх входять особи з порушеннями слуху, для яких жестова мова є основним або одним з основних засобів спілкування. Підкреслено, щзо єдиним правильним терміном, визнаним Всесвітньою федерацією глухих та Всесвітньою асоиіацією перекладачів жестової мови щуодо фахівця у сфері жестово-словесного перекладу, $є$ «перекладач жестовоі мови», інші терміни є хибними.

Акцентовано увагу на виокремленні освітніх перекладачів жестової мови з-поміж інших груп фахівців з перекладу з жестової мови на словесну, і навпаки - унаслідок професійної діяльності в освітній сфері. Зазначено, щьо в Україні підготовкою освітніх перекладачів жестової мови займається лише громадська організачія «Українське товариство глухих». Розкрито суть поняття «освітній перекладач жестової мови» $i$ «глухий студент». Висвітлено кількісну характеристику спеціальних шкіл для глухих.

Надано роз'яснення, щзо фахову компетентність освітнього перекладача жестової мови визначають різні чинники, з-поміж яких виділяється рівень жестомовної комунікативної компетентності.

Стисло розглянуто поняття «українська жестова мова», розкрито ї̈ складники. Підкреслено роль рецептивних та репродуктивних навичок, які є фундаментальними для жестового перекладу, та звернено увагу на дактилювання, щзо є додатковим елементом жестового мовлення; побіжно вказано на відмінності дактилювання перекладачів жестової мови та носіїв ијєї мови. Наведено приклади розрізнення украӥнської жестової мови та калькованого жестового мовлення. Висвітлено унікальні особливості украӥнської жестової мови; вказано наявність властивої ій артикуляції.

Перераховано слабкі сторони освітніх перекладачів жестової мови та підкреслено важливість застосування ними немануального компоненту в навчальному процесі. Підкреслено умову визнання себе спільнотою Глухих ие бути ї̈ членом та визнавати і сприймати культуру Глухих, щзо є запорукою фахового зростання.

Ключові слова: вищза школа, глухий студент, жестова мова, компетентність, перекладач.

Nataliia ADAMIUK, orcid.org/0000-0002-4927-6257 Candidate of Pedagogical Sciences, Senior Researcher at the Department of Sign Language Education Institute of Special Pedagogics and Psychology after Mykola Yarmachenko National Academy of Educational Sciences of Ukraine (Kyiv, Ukraine)natbor07@gmail.com

\section{PROFESSIONAL COMPETENCE OF EDUCATIONAL SIGN LANGUAGE TRANSLATORS}

This article lists a number of international and national documents, after which the change in the educational policy on social protection and the language rights of the Deaf began. It is noted that the latter include persons with hearing impairment, for whom sign language is the main means of communication. It is emphasized that the only correct term recognized by the World Federation of the Deaf and the World Association of Sign Language Interpreters for a specialist in the field of Sign Language Translation is «Sign Language Translator». Other terms are wrong.

Emphasis is placed on the separation of sign language educational translators from among other groups of specialists in translation from sign language to verbal and vice versa as a result of professional activity in the educational field. 
It is noted that in Ukraine only the Ukrainian Society of the Deaf public organization is engaged in the preparation of sign language interpreters. The essence of the concept of «educational sign language translator» and «deaf student» is revealed. The quantitative characteristics of special schools for the deaf are highlighted.

It is explained that the professional competence of the sign language translator is determined by various factors, among which is the level of gestural communicative competence.

The concept of "Ukrainian Sign Language" is briefly discussed, its components are revealed. Examples of differences between the Ukrainian sign language and tracing of sign language are given. The role of receptive and reproductive skills, which are fundamental to gesture translation, is emphasized. Attention is paid to the manual alphabet, which is an additional element of sign language. The focus is on the difference between the finger alphabet of sign language translators and the native speaker of sign language. The unique features of sign language are highlighted. Indicated on the presence of articulation, which is inherent only to her.

The weaknesses of translators are listed and the importance of using facial expressions in the educational process is emphasized. The importance of recognizing and perceiving the culture of the deaf is emphasized.

Key words: high school, deaf student, sign language, competence, translator.

Постановка проблеми. 70-і роки минулого століття знаменують початок зміни освітньої політики стосовно глухих осіб у питанні отримання ними вищої освіти. Це стало можливим унаслідок переосмислення освітніх можливостей глухих осіб; отже, в Україні починають відкриватися спеціальні групи глухих студентів; першими ВН3, які надали таку можливість, стали Київський технікум легкої промисловості (нині - Київський державний коледж легкої промисловості) та Херсонське медичне училище (нині - Херсонський державний медичний коледж) (Адамюк, 2018: 197).

Докорінна зміна освітньої політики припадає на кінець минулого та початок нового століття. Резолюції Європейського парламенту щодо жестових мов $(1988,1998)$, Стандартні правила забезпечення рівних можливостей для інвалідів: Резолюція Генеральної Асамблеї ООН (1993), Конвенція ООН «Про права інвалідів (2006), Брюсельська декларація щодо жестових мов Європейського Союзу (2010), Закон України «Про основи соціальної захищеності інвалідів в Україні» (2013) та низка міжнародних і національних законодавчих документів стали можливими внаслідок демократичної політики ООН щодо захисту і збереження мови кожної меншини, зокрема і лінгвальних прав Глухих, що означає гарантування глухим особам права на вільне використання і всебічний розвиток жестових мов (далі - ЖМ), носіями яких вони є. Разом із тим декларується їхнє право на повний з іншими доступ до інформації і до всіх сфер життєдіяльності людини, серед іншого i шляхом використання послуг професійних перекладачів ЖМ. У Брюсельській декларації щодо ЖМ Свропейського Союзу зазначається: «...глухі і слабкочуючі Європи є користувачами і хранителями багатьох місцевих національних жестових мов і є громадянами з особливими потребами, наділеними рівними правами нарівні 3 іншими лінгвістичними і культурними меншинами» (Брюсельська декларація, 2010: 1). Тому ЖМ Глухих є їхньою рідною мовою, і вони мають повне право користуватися нею у своєму житті.

Аналіз досліджень. Дослідженнями зарубіжних науковців встановлено, що ЖМ є повноцінними мовами з їхніми граматикою і синтаксисом, так само як і звукові (тобто словесні, далі - СМ) мови (Stokoe W., Casterline D, Croneberg C,. (1965), Boyes Bray D., Sutton-Spence R., Woll B. (1999), Scott K. Liddell (2003 p.), Papaspiro T. (2008 p.). Питанню жестового перекладу, підготовці перекладачів ЖМ увагу надавали Crasborn O., Bloem T. (2009), Dean R., Pollard R. (2005), Hermans D., Dijk R. Van, Christoffels I. (2007), Janzen T., Korpiniski D. (2005), Napier J., Barker R. (2004), Stratiy A. (2005), Wit M. de (2012).

Мета статті - розкрити фахові компетентності освітнього перекладача ЖМ у спілкуванні з підопічними - глухими студентами спеціальної групи BH3.

Виклад основного матеріалу. У законопроєкт України «Про українську жестову мову» (Адамюк, 2017: 12) його авторами внесено єдиний термін на позначення особи, яка здійснює/надає жестовий переклад, 3 метою привернення всіх працівників державних та комунальних установ щодо правильного застосування терміна та хибності таких з них, як «сурдоперекладач», «перекладач-дактилолог». Єдиний і правильний термін, визнаний Всесвітньою федерацією глухих (WFD) та Всесвітньою асоціацією перекладачів ЖМ (WASLI), це «перекладач жестової мови» - фахівець у сфері перекладу між ЖМ і СМ (Адамюк, 2017: 13). Переклад перекладачем ЖМ надається двом сторонам: він перекладає жестове мовлення глухої особи для особи з нормальним слухом усним мовленням, і навпаки - усне мовлення останньої транслює в жестове для глухої жестомовної особи.

В Україні розпочався процес диференціації зазначених фахівців відповідно до місця їхньої роботи; чітко визначене коло перекладачів ЖМ, 
які працюють у регіональних організаціях ВГОI «Українське товариство глухих»; формується стихійно, на основі звернення самих Глухих до перекладачів ЖМ, група фахівців із жестового перекладу, які його здійснюють у правових установах (суд, нотаріат, поліція); так само формується група перекладачів ЖМ, які обслуговують Глухих у посольствах/консульствах та центрах візової допомоги. Також чітко проведена межа від інших для освітніх перекладачів ЖМ: вони жестовий переклад для жестомовних осіб здійснюють у вищій школі (у дошкільних та шкільних закладах вони відсутні). Підготовка та підвищення кваліфікації всіх перекладачів ЖМ здійснюється УТОГ та тими ВНЗ України, які мають ліцензію $\mathrm{MOH}$ України на проведення такої діяльності. Навчання перекладачів ЖМ здійснюється за методиками та програмами, затвердженими МОН України (Адамюк, 2019: 13).

Що стосується терміну «глухий студент», то цеза медичними показниками особа 3 повною втратою слуху (глуха особа) чи частковою його втратою (слабкочуюча особа). У недалекому минулому згадані особи були випускниками спеціальних загальноосвітніх шкіл для дітей 3 порушеннями слуху і мали середній чи високий рівень володіння украінської жестової мови УЖМ. Мережа спеціальних загальноосвітніх шкіл для зазначеної категорії дітей була досить розгалуженою і містила 58 спеціальних шкільних закладів (наразі функціонують 54 такі заклади, і відчутно існує тенденція скорочення шкіл у зв'язку з т.зв. оптимізацією, пов'язаною 3 фінансовою спроможністю місцевої влади). Щодо усного мовлення колишніх учнів зазначених шкіл, то воно варіюється від зрозумілого мовлення з чіткою дикцією та фразовою мовою до малозрозумілого і незрозумілого усного мовлення (Адамюк, 2016: 8).

Наразі з'являються студенти 3 порушеннями слуху, які здобули повну середню освіту в загальноосвітніх школах шляхом інклюзивного навчання. Вони можуть не знати УЖМ взагалі, оскільки спираються на отримання інформації завдяки потужним і високоякісним слуховим апаратам та кохлеарним імплантам. Зазвичай вказані глухі студенти можуть навчатися у ВНЗ інклюзивно, втім, в останні роки фіксується прагнення батьків влаштувати «інклюзивних» дітей у спеціальні групи глухих студентів, в яких другою ключовою фігурою навчального процесу, крім викладача, є освітній перекладач ЖМ. Слід підкреслити, що для жестомовних студентів існують чинники привабливості освітнього перекладача ЖМ, до яких відносяться стать; вік; освіченість перекла- дача; його життєвий досвід та активна життєва позиція; сучасний погляд на речі й сучасні шляхи розв'язання різних питань, пов'язаних з освітою; дотримання принципів рівності та ділового партнерства, позитивні риси тощо. Втім, усі зазначені чинники можуть стати не актуальними, якщо жестомовна комунікативна компетентність освітнього перекладача ЖМ як чинник привабливості матиме високу оцінку жестомовних студентів.

Фахова компетентність освітнього перекладача ЖМ включає в себе знання про: а) УЖМ, її складники та основні мовознавчі розділи; б) основні правила дактилювання; в) відмінності між УЖМ та калькованим жестовим мовленням (КЖм); г) граматико-синтаксичні особливості рідної мови Глухих; д) артикуляцію, властиву лише УЖМ; е) немануальний компонент мови; є) ознаки самобутньої культури Глухих. Окрім того, важливими показниками фахової майстерності та компетентності освітнього перекладача ЖМ $є$ рецептивні та репродуктивні його навички.

Кожний перекладач ЖМ має знати, що українська жестова мова - природна візуально-жестова мовна система 3 власною лексико-граматичною структурою, що сформувалась еволюційним шляхом і використовується як основний або один 3 основних засобів спілкування жестомовних осіб, які постійно проживають або впродовж тривалого часу проживали на території України. Вона складається 3 двох рівнозначних за важливістю складників: мануального і немануального. Якщо знаряддям мануального компоненту є руки, то знаряддям немануального компоненту є вираз обличчя, міміка. I якщо перекладач ЖМ достатньо добре володіє мануальним компонентом (конфігурація, рух, позиція жестової одиниці; типи і види жестів тощо), то опанування немануального компоненту дається складно, саме цей складник ЖМ становить межу розрізнення між перекладачами ЖМ і Глухими, між високопрофесійними перекладачами ЖМ і перекладачами ЖМ нижчого рівня фаховості.

Що стосується дактилювання, специфічного пальцевого мовлення, засобом якого інформація передається за допомогою дактилем (положення пальця/пальців на позначення певної букви), то фахова компетентність освітнього перекладача ЖМ полягає у відтворенні знаків, характерних для Глухих. Часто положення окремої дактилеми від інших відрізняється від положення (розташування в просторі) у мовному суцільному потоці; дактилювання глухою особою здійснюється на місці, без руху в бік; вона ж у процесі дактилювання лише паузами різної тривалості позначає 
розділові знаки; більшість перекладачів ЖМ цього не дотримується з різних причин.

Якщо УЖМ - це мовна система зі своїми нормами, то КЖм - це не мова, а мовлення, і підтвердженням цьому є мала літера $M$ в абревіатурі. КЖм - вторинна знакова система, що засвоюється на основі і в процесі вивчення глухою особою словесної мови $(\mathrm{CM})$, в якій жести є еквівалентами слів СМ, а порядок їхньої послідовності відповідає послідовності слів СМ. Іншими словами, КЖм - це прообраз СМ і з УЖМ воно запозичило лише засіб передачі - жести. Проблемою для перекладачів становить система норм УЖМ і дотримання мовних норм; жестові одиниці, які властиві лише УЖМ і не властиві КЖм; побудова речення за правилами УЖМ. Наведемо два приклади граматико-синтаксичних особливостей УЖМ, щоб зрозуміти сутність «каменів спотикання» під час жестового перекладу освітніми перекладачами ЖМ: 1) порядок жестосполучення відмінний словесному, н-д: у СМ прикметник здебільшого передує іменнику (довгі штани, зелений ліс), в УЖМ чітко діє інше правило: жест на позначення предмету відтворюється першим, за ним йде жест на позначення ознаки предмета (ШТАНИ ДОВГІ, ЛІС ЗЕЛЕНИЙ); 2) словесне речення Після багатьох років судової тяганини йоу поталанило виграти суд, перекладене КЖм, виглядатиме так: ПІСЛЯ / БАГАТО / РІК / СУД / ТЯГНУТИ / ВІН / ЩАСТЯ / ВИГРАТИ / СУД (нами для читабельності обрано спрощену подачу прикладу, де прописні літери означають застосування жестових одиниць). Подане речення СМ у перекладі на УЖМ читатиметься так: СУД / ТЯГНУТИ / ТЯГНУТИ / ЧОЛОВІК / ПОЩАСТИТИ / ВДАТИСЯ / ВИГРАТИ / СУД. Завважимо різну кількість мовних одиниць у двох реченнях, різну синтаксичну побудову речень, також мовна одиниця виграти у двох реченнях має іншу жестову картину (Адамюк, Чепчина, 2008: 175).

Втім, в освітньому перекладачу варто мати високий рівень як УЖМ, так і КЖм, оскільки для задоволення комунікативних потреб студентів усієї групи перевага надається КЖм під час лекцій викладача, при зворотньому перекладі, тобто жестово-словесного, освітній перекладач ЖМ працює над перекладом власне УЖМ.

Прийнято вважати, що артикуляція (рухи губ, що супроводжують звук) наявна за усного мовлення, насправді ж, вона властива і жестовому мовленню. В Україні вперше над цим питанням почали працювати наукові співробітники відділу навчання ЖМ Інституту спеціальної педагогіки і психології ім. М. Ярмаченка, оскільки було помі- чено, що за рухами губ під час відтворення, наприклад, лексичної одиниці ОДНАКОВО читається an, тобто зміст промовляння губ і зміст поняття жестової одиниці не збігаються. Освітні перекладачі, маючи досвід роботи з Глухими, повинні володіти і даною компетентністю зчитування артикуляції з губ глухого співрозмовника.

Під лексичною одиницею УЖМ виступають: жест, стале жестосполучення, речення. Їх набір, котрий необхідний для вирішення комунікативних потреб глухих студентів, зумовлений контекстом діяльності освітнього перекладача ЖМ у взаємодії $з$ ними. I лексична навичка - це синтезована дія на вибір лексичної одиниці УЖМ відповідно задуму і її правильного сполучення з іншими одиницями. Ця дія $є$ однією 3 умов виконання мовленнєвої діяльності користувача ЖМ. Якщо навичка має всі необхідні якості (якщо сформовані всі механізми, на яких вона заснована), то вона здатна включатися в мовленнєву діяльність і слугує умовою для iї успішного здійснення. Таким чином, усі лексичні навички УЖМ - умови функціонування показу, відтворення. Ми визначаємо репродуктивні та рецептивні лексичні навички. Репродуктивні лексичні навички - правильне вживання активного мінімуму у відтворенні жестів, тобто жестовому мовленні, згідно із ситуацією спілкування і метою комунікації. Рецептивні лексичні навички - розпізнавання і розуміння лексичних одиниць активного і пасивного жестівника під час сприймання і відтворення. Таким чином, навички освітнього перекладача ЖМ, рецептивні й репродуктивні, є запорукою фахової компетентності (Адамюк, 2012: 68)

Як ми зазначали, розуміння і володіння немануальним компонентом, який має такі види: міміка обличчя (рухи очей, рухи брів, артикуляція, рухи щік); погляд (напрям, рух); рухи голови (нахили, кивки тощо); рухи тіла (нахили корпусу, рухи плечей тощо) - це показник високої фахової компетентності та майстерності перекладача ЖМ. Немануальний компонент збагачує ЖМ, значення його розкривається на трьох рівнях: морфологічному, синтаксичному і просодичному. Передумовою вивчення, сприймання, розпізнавання і відтворення немануальних жестів $є$ тісна комунікативна взаємодія освітнього перекладача з Глухими (Адамюк, 2018: 6).

У цій статті особи з порушеннями слуху позначаються нами словом «Глухі» 3 великої букви недаремно, бо Глухий - це особа, яка вважає себе членом певної спільноти, 3 такими ознаками: використання природної ЖМ; існування об'єднань Глухих; фольклор і мистецтво Глухих; ендогамні шлюби; культурна самоідентифікація 
представників спільноти Глухих; правила і норми поведінки; позитивне сприйняття глухоти тощо (Адамюк, 2018: 127). Щодо перекладачів ЖМ у питанні культури Глухих, то вони не можуть бути фахівцями своєї справи, не знаючи, не визнаючи iï; навпаки, багато хто позитивно сприймає культуру Глухих і $є$ членом спільноти Глухих.

Висновки. Підсумовуючи зазначене вище, можемо коротко констатувати:

1. Сдиним правильним терміном, який визнаний Всесвітньою федерацією глухих (WFD) та Всесвітньою асоціацією перекладачів ЖМ (WASLI) щодо фахівця у сфері перекладу між ЖМ і СМ, є «перекладач жестової мови».

2. В Україні розпочався процес диференціації перекладачів ЖМ відповідно до сфери їхньої діяльності, тому 3-поміж них виділяється окрема група фахівців - освітні перекладачі ЖМ.

3. Фахову компетентність освітнього перекладача ЖМ визначають різні чинники, втім, 3-поміж них виділяється рівень жестомовної комунікативної компетентності.

\section{СПИСОК ВИКОРИСТАНИХ ДЖЕРЕЛ}

1. Адамюк Н. Б. До питання про проект Закону України «Українська жестова мова». Збірник наукових праџь «Освіта осіб з особливими потребами: иляхи розбудови». 2017. Випуск 12. С. 10-18.

2. До проблеми розроблення вітчизняної концепції бімодально-білінгвального підходу до навчання глухих та напівглухих осіб / Н. Адамюк. Науковий журнал «Інноваиійна педагогіка». 2018. Вип. 7. Т. 1. С. 125-130.

3. Адамюк Н. Б. Освітній перекладач жестової мови: кадрове забезпечення комунікативних потреб жестомовних здобувачів освіти. Особлива дитина: навчання і виховання. 2019. № 4 (92). С. 7-14.

4. Адамюк Н. Б. Особливості вивчення лексики української жестової мови глухими учнями початкової школи : дис. ... на здобуття наук. ступеня канд. пед. наук : 13.00 .03 «Корекційна педагогіка». Київ : Інститут спеціальної педагогіки НАПН України, 2012. 221 с.

5. Адамюк Н. Б. Перекладач у навчальному закладі як модель жестової мови для глухих студентів. Збірник наукових прачь «Педагогічні науки». 2016. Випуск LXIX. Том 3. С. 7-12.

6. Адамюк Н. Б. Проблемні аспекти отримання вищої освіти в Україні жестомовними глухими особами. Збірник наукових пращь «Педагогічні науки». 2018. Випуск LXXXIII. Том 1. С. 194-202.

7. Адамюк Н. Б., Чепчина I. І. Синтаксичні особливості УЖМ: на прикладі простого речення. Жестова мова й сучасність. 2008. Вип. 3. С. 124-135.

8. Адамюк Н. Б. Сучасний погляд на жестову мову. Збірник наукових праць «Освіта осіб з особливими потребами: иляхи розбудови». 2018. Випуск 14. С. 11-20.

9. Брюсельська декларація 2010 року щодо жестових мов Свропейського Союзу (Брюссель, 19 листопада 2010 року.).

\section{REFERENCES}

1. Adamiuk N. B. Do pytannia pro proekt Zakonu Ukrainy «Ukrainska zhestova mova» [To the Question on the project of Act the 'Ukrainian Sign Language']. Education of persons with special needs: way of development, 2017, Vol. 12, pp. 10-18 [in Ukrainian].

2. Adamiuk N, Drobot O., Zamsha A., Fedorenko O, (2018). Do problemy rozroblennia vitchyznianoi kontseptsii bimodalno-bilinhvalnoho pidkhodu do navchannia hlukhykh ta napivhlukhykh osib [Issues to development the Ukrainian conception of bimodal-bilingual approach to education of deaf and hard-of-hearing]. Innovative Pedagogy, 2019, Vol 7, Part 1, pp.125-130 [in Ukrainian].

3. Adamiuk N. B. Osvitnii perekladach zhestovoi movy: kadrove zabezpechennia komunikatybnykh potreb zhestomovnykh zdobuvachiv osvity [Sign Language Educational Translator: Staffing the Communicative Needs of Sign Language Education Applicants]. Exceptional child: teaching and upbringing, 2019, Vol. 4(92), pp. 7-14.

4. Adamiuk N. B. Osoblyvosti vyvchennia leksyky ukrainskoi zhestovoi movy hlukhymy uchniamy pochatkovoi shkoly [Features of studying the vocabulary of Ukrainian Sign Language by deaf elementary school students]. PhD thesis. Kyiv: ISP of NAES of Ukraine, 2012 [in Ukrainian].

5. Adamiuk N.B. Osoblyvosti vyvchennia leksyky ukrainskoi zhestovoi movy hlukhymy uchniamy pochatkovoi shkoly [Features of studying the vocabulary of Ukrainian Sign Language by deaf elementary school students]. PhD thesis. Kyiv: ISP of NAES of Ukraine, 2012 [in Ukrainian].

6. Adamiuk N. B. Problemni aspekty otrymannia vyshchoi osvity v Ukraini zhestomovnymy hluhymy osobamy [Problematic Aspects of Higher Education of Signing Deaf People in Ukraine]. Scientific Journal of Kherson State University Series: Pedagogical Sciences, 2018, Vol. LXXXIII, part 1, pp.194-202 [in Ukrainian].

7. Adamiuk N. B., Chepchyna I. I. Syntaksychni osoblyvosti UZhM: na prykladi prostoho rechennia [Syntactic features of UJM: as an example of a simple sentence]. Sign language and modernity, 2008, Vol.3, pp. 124-135 [in Ukrainian].

8. Adamiuk N. B. Suchasnyi pohliad na zhestobu movu [The modern view on sign language]. Education of persons with special needs: way of development, 2018, Vol.14, pp. 11-20.

9. Brussels Declaration on Sign Languages in the European Union (2010) [in English]. 